\title{
Enhancement of Tiger Shrimp Penaeus monodon Resistance to White Spot Syndrome Virus by Overexpression of Antiviral Gene
}

\author{
Andi Parenrengi ${ }^{\mathbf{1}^{* \dagger}}$, Andi Tenriulo ${ }^{\mathbf{1}}$, Alimuddin Alimuddin ${ }^{2}$ and Sukenda Sukenda ${ }^{2}$ \\ ${ }^{1}$ Research Institute for Brackishwater Aquaculture and Fisheries Extension, Maros, 90511, Indonesia \\ ${ }^{2}$ Faculty of Fisheries and Marine Science, IPB University, Bogor 16680, Indonesia \\ *For correspondence: andi_parenrengi@hotmail.com \\ ${ }^{\dagger}$ Contributed equally to this work and are co-first authors \\ Received 20 July 2020; Accepted 10 October 2020; Published 10 January 2021
}

\begin{abstract}
White spot syndrome virus (WSSV) is a significant cause of tiger shrimp mortality, and has a profound economic impact on commercial shrimp farming. A transgenic technology provides an effective method to control the viral disease by increasing the shrimp resistance. The study aimed to assess the overexpression of the PmAV (Penaeus monodon antiviral) gene on the embryo/larvae of tiger shrimp and the performance of transgenic shrimp by WSSV-challenge test. Transfection of pProAVPmAV gene construct into the embryo was conducted using jetPEI reagent. Transient antiviral gene expression was detected at 12, 18, 24 and $30 \mathrm{~h}$ post transfection (hpt). The tiger shrimp larvae of PL-25 were challenged by waterborne infection technique. Survival and expression of antiviral genes were observed after challenge test. The results showed that the PmAV gene and the jetPEI reagent did not have the toxicity to the tiger shrimp larvae. The transient antiviral gene expression was exhibited at $12 \mathrm{hpt}$ until the peak reached within $24 \mathrm{hpt}$ and then decreased slightly at 30 hpt. This suggested that the expression of PmAV during infection was an up-regulated sign. The challenge test result showed that the transgenic tiger shrimp exhibited higher resistance $(P<0.05)$ to the WSSV infection $(95.6 \%$ survival rate) than the control shrimp $(71.1 \%$ survival rate). The 47-day transgenic tiger shrimp did not show significant difference $(P>0.05)$ in body weight and length gain as well as appearance, morphology, and activity from normal control shrimps. (C 2021 Friends Science Publishers
\end{abstract}

Keywords: Antiviral gene; Challenge test; Overexpression; Tiger shrimp; Transfection; WSSV

\section{Introduction}

White spot syndrome virus (WSSV) remains the most feared pathogenic agent for the shrimp aquaculture disease since its emergence in 1992 (Escobedo-Bonilla 2011). To date, WSSV is present in most of the world's shrimp farming areas and causes significant economic losses to the shrimp aquaculture industry. However, no effective chemicals or drugs are currently reported for control of shrimp viral diseases. Approaches commonly used to battle shrimp diseases include vaccination, immunostimulation, and environmental management. The severe impact of viral disease on cultured shrimp has resulted in a critical demand for application of advanced biotechnology. The use of genetic transfer technology is a new strategy to produce the resistant shrimp (Lu and Sun 2005).

Transgenic fish/shrimp development offers excellent experimental models for basic scientific research, environmental toxicology and biotechnology applications (Wakchaure et al. 2015). As a model target species, Yasawa et al. (2005) evaluated gene transfer methods for black tiger shrimp using green fluorescence protein (GFP) and chloramphenicol acetyl transferase (CAT) as a marker gene. More recently, growth-enhanced transgenic organisms have been the main research subject in many fish species through the introduction of growth hormone gene constructs (Alzaid et al. 2018; McClelland et al. 2020). However, transgenic technology provides a great prospect in developing strains that have high resistance to disease-causing pathogens. A potential effort that can be done in increasing disease resistance is the production of transgenic aquatic animals that contain antibacterial or antiviral genes. The discovery of cecropin antibacterial protein in insects by Steiner et al. (1981) was the beginning of antimicrobial research, which then identified several other antimicrobials. Several antimicrobials have been identified in mammals (Lehrer et al. 1993), amphibians (Bevins and Zasloff 1990) and insects (Hoffmann et al. 1996) where organisms containing the coding gene show better resistance to disease.

Anderson et al. (1996) firstly proved by in vivo that the resistance of rainbow trout Oncorhynchus mykiss could be increased by transferring the coat protein of the virus. The introduction of cecropin construction increased the resistance to bacteria in channel catfish (Dunham et al. 2002)

To cite this paper: Parenrengi A, A Tenriulo, A Alimuddin, S Sukenda (2021). Enhancement of tiger shrimp Penaeus monodon resistance to white spot syndrome virus by overexpression of antiviral gene. Intl J Agric Biol 25:277-284 
and in rainbow trout (Chiou et al. 2014). The related finding in transgenic medaka fish, which had higher resistance compared to non-transgenic fish against the bacteria Vibrio spp. and Pseudomonas spp. (Sarmasik et al. 2002). Meanwhile, recombinant DNA approaches, especially DNA vaccines have begun to be applied to aquaculture. Injecting Atlantic salmon with a glycolotein IHNV encoded plasmid with a pCMV promoter controller shows significant protection in the presence of virus neutralizing antibody formation after immunization and the titer increases after the challenge test (Traxler et al. 1999). As with other antimicrobials, the lysozyme gene has been reported to be one of the disease-resistant coding genes, especially non-specific antimicrobials (Austin and Allen-Austin 1985).

In crustaceans, especially shrimp, increment of resistance at the molecular level is still limited. The discovery of penaeidin encoding antimicrobial genes opens opportunities in enhancing shrimp immunity against pathogenic infection. Penaeidin application showed an effect to increase resistance in the white shrimp Litopenaeus vannamei (Destoumieux et al. 1997). The transfer of a new antiviral gene was initiated in $L$. vannamei through the introduction of TSV-CP (the coat protein-encoding gene from TSV) (Sun et al. 2005). Lu and Sun (2005) reported that by introducing the TSV-CP gene, transgenic shrimp showed significantly higher survival compared to normal shrimp. Based on the results of these studies, the efforts to enhance the resistance of tiger shrimp provide a positive confidence to be carried out. Previous studies exhibited successfully isolated the promoter dan PmAV antivirus gene from tiger shrimp (Parenrengi et al. 2009a, b) and introducing pProAV-EGFP gene construct "all shrimp" into the tiger shrimp for promoter activity assessment (Parenrengi et al. 2018). This study aimed to assess the pattern of PmAV gene expression in embryos/larvae and the performance of transgenic tiger shrimp larvae through WSSV challenge test.

\section{Materials and Methods}

\section{Antivirus gene construction}

The construction of the pProAV-PmAV antiviral gene was created by ligating promoter antiviral (ProAV) (Parenrengi et al. 2009a) and PmAV gene (Parenrengi et al. 2009b) which were isolated from the tiger shrimp. Promoter ProAV was ligated at BamHI site and PmAV gene sequence was ligated at SalI site in pBlueskript-SK vector. Orientation test of ProAV-PmAV ligation was carried out using the PCR method with a set of primers: ProAV-F 5'gtcggatccagtccacactccatcaa $-3^{\prime}$ and PmAVSalI-R 5'- ttg tcgactcctttagaatatttattcttg -3 '. The PCR reaction was $0.05 \mu \mathrm{L}$ Taq Polymerase; $0.8 \mu \mathrm{L} \mathrm{dNTP} \mathrm{mix;} 1 \mu \mathrm{L} 10 \times$ buffer; $0.8 \mu \mathrm{L}$ $\mathrm{MgCl}_{2} ; 1 \mu \mathrm{L}$ DNA template; 10 pmol each primer; and 4.35 $\mu \mathrm{L}$ sterile distilled water. The PCR was programed by pre- denaturation temperature of $94^{\circ} \mathrm{C}$ for $3 \mathrm{~min}, 30$ cycles for (denaturation of $94^{\circ} \mathrm{C}$ for $30 \mathrm{~s}$, annealing of $60^{\circ} \mathrm{C}$ for 30 $\mathrm{s}$ and extension of $72^{\circ} \mathrm{C}$ for $40 \mathrm{~s}$ ), and a final extension of $72^{\circ} \mathrm{C}$ for $3 \mathrm{~min}$. The PCR results were run on $1.0 \%$ agarose gel to determine the formed DNA fragments. Bacterial clones showing positive PCR results with fragments about $1.2 \mathrm{~kb}$ indicated the appropriate ligation direction.

\section{Tiger shrimp maintenance and embryo collection}

Tiger shrimp brood stocks were maintained in a hatchery facility of nucleus centre, Research Institute for Brackish water Aquaculture and Fisheries Extension, South Sulawesi, Indonesia, and fed with fresh squid Loligo spp. and seaworm Nereis spp. of $15 \%$ per body weight twice a day. Adult female (22.9-27.8 cm in total length and 125-237 g in body weight) and male shrimps (18.5-22.3 cm in total length and 61-112 $\mathrm{g}$ in body weight) were stocked to mating tanks, which were equipped with a constant water flow for $300 \%$ per day. The mature gonadal females were then transferred for continuous monitoring to individual spawning tanks. The spawning usually occurred at night. The fertilized eggs (embryos) were immediately collected approximately 5 min after spawning.

\section{Antivirus gene transfection}

Bacteria carrying pProAV-PmAV gene construct were cultured using LB media. The pProAV-PmAV plasmid was isolated using GF-1 Plasmid DNA Extraction Kit by following the manual kit procedure. Quantity and quality of plasmid isolates were measured at wavelengths of $260 \mathrm{~nm}$ and $280 \mathrm{~nm}$ using a UV-VIS spectrophotometer. The plasmid concentration was calculated by referring to the formula that has been developed by Linacero et al. (1998); whereas the plasmid purity was calculated from the absorption ratio of $260 \mathrm{~nm}$ and $280 \mathrm{~nm}\left(\mathrm{OD}_{260} / \mathrm{OD}_{280}\right)$.

The new spawning egg collection and transfection procedures using the pProAV-PmAV plasmid refer to the standard pProAV-EGFP gene transfection protocol developed by Parenrengi et al. (2018). In order to determine a toxicity of transfection reagent, two control treatments were applied to observe the hatching rate of tiger shrimp embryo. The positive control (PC) was transfection procedure without using the plasmid of gene construct, while the negative control (NC) was without plasmid and transfection reagent. The three treatments had 5 replications (3 replicates for hatching rate observation and 2 replications for sampling gene insertion and expression). The transfection of the pProAV-PmAV gene construct was carried out in two trial groups, in which the egg concentrate was 370 eggs $/ 2 \mathrm{~mL}$ in the first trial and $235 \mathrm{eggs} / 2 \mathrm{~mL}$ in the second trial. The transfected eggs were rinsed with sterile seawater and stocked to the stopples filled with $2 \mathrm{~L}$ seawater for incubation. The stopples were placed in water 
bath with heater to maintain the stabilized temperature. The hatching rate of embryo was counted after the incubation egg for $24 \mathrm{~h}$. To determine the presence or absence of an exogenous PmAV antiviral gene, genomic DNA and its expression of PmAV antiviral genes by cDNA synthesis from RNA were performed in tiger shrimp larvae.

\section{WSSV challenge test}

Performance of transgenic tiger shrimp was assessed through a larvae challenge test with WSSV, where nontransgenic shrimp larvae were used as a control treatment. Both transgenic and non-transgenic tiger shrimp larvae were maintained according to standard larval rearing procedures until they reached to PL-25 stage. The WSSV was isolated from naturally infected tiger shrimp by centrifugating the shrimp liquid at $6,000 \mathrm{rpm}$ for $15 \mathrm{~min}$ and filtering the supernatant with $0.45 \mu \mathrm{m}$ in mesh size.

The culture tank was disinfected with soaking $30 \mathrm{ppm}$ chlorine for one day and then neutralized with $30 \mathrm{ppm}$ sodium-thiosulfate. Each tank was filled with filtered seawater by a filter membrane as much as $2 \mathrm{~L}$ and equipped with aeration system. Tiger shrimp larvae PL-25 were stocked into a tank with a density of 15 shrimps. WSSV inoculum was infected into shrimp larvae with a concentration of $2 \mathrm{~mL} \mathrm{~L}^{-1}$, referring to the $\mathrm{LC}_{50}$ value that has been done in preliminary study. The treatments of this experiment were the WSSV challenge test on transgenic (A) and non-transgenic tiger shrimp larvae (B), and nontransgenic shrimp larvae without challenge test $(C)$. Each treatment has 4 replications ( 3 for observation of survival larvae and 1 for observation of antiviral gene expression). During the experiment, the shrimp were fed with pellet larvae in ad-libitum 3 times a day. Observation of mortality for survival rate and sampling of larval hepatopancreas for gene expression analysis was performed at 6, 12, 24, 48, 72, 96, and $120 \mathrm{~h}$ post transfection (hpt).

\section{Analysis of PmAV gene expression}

For analysis of transient antiviral gene expression in embryos and tiger shrimp larvae, total RNA was extracted using 50 embryos/larvae (pooled samples) and then followed by cDNA synthesis. Analysis of gene expression was performed using RT-PCR technique in several stages of observation, namely: $12,18,24$, and $30 \mathrm{~h}$ post transfection (hpt). Calculation of the hatching rate was done after the eggs incubated for $24 \mathrm{~h}$. The PmAV antiviral gene and its expression were detected by a semi-quantitative PCR technique, in which egg samples without transfection were used as controls in this study.

Confirmation of PmAV genes insertion to individual larvae was carried out by extracting genomic DNA in eight tiger shrimp larvae $(0.15 \pm 0.05 \mathrm{~g}$ in weight $)$ randomly taken for the two trials of transfection. In observing the expression of the PmAV gene in a challenge test, hepatopancreas of larvae (10 mg) were collected for RNA extraction (Parenrengi et al. 2009b). Briefly, RNA total was isolated using an isogen kit and was then continued with cDNA synthesis using the RTG You-Prime First Strand Beads. The cDNA was used as a DNA template in the PCR amplification process using PmAV-F primers: 5'tagtgcatgcatatgggtcatacaatccta $-3^{\prime}$ and PmAV-R: 5'ctgtctcgagctatgtgtcctgctttcaca -3 ', with a target fragment of $513 \mathrm{bp}$. The $\beta$-actin gene expression of tiger shrimp was used as a control gene expression (Sriphaijit and Senapin 2007). The amplification process was carried out on the GenAmp AB-7200 PCR machine with a pre-denaturation of $94^{\circ} \mathrm{C}$ for $3 \mathrm{~min} ; 35$ cycles for (denaturation of $94^{\circ} \mathrm{C}$ for $30 \mathrm{~s}$, annealing of $58^{\circ} \mathrm{C}$ for $30 \mathrm{~s}$, and extension of $72^{\circ} \mathrm{C}$ for $45 \mathrm{~s}$ ); and the final extension of $72^{\circ} \mathrm{C}$ for $3 \mathrm{~min}$. To ensure the success of target DNA fragment amplification, the PCR results were run at $1.0 \%$ agarose gel and visualized by the Gel Documentation System. The VC 100 bp Plus DNA Ladder was used as a molecular weight marker.

\section{Juvenile tiger shrimp production}

Larval transgenic tiger shrimp were kept in a controlled tank in-door system with a density of 150 shimp $\mathrm{m}^{-3}$ to produce juveniles for 1.5 months rearing period. Larvae were fed with pellet with a dose of $30 \%$ of body weight twice a day. To determine the effect on introduction of the PmAV antiviral gene in shrimp growth of total length and body weight measurements and morphological appearance, shrimp larvae were kept under controlled conditions until juvenile stage (in 47 days old), where non-transgenic tiger shrimp were used as a control treatment.

\section{Data analysis}

The results of cracking, orientation test of pProAV-PmAV gene construct, expression of antiviral gene in embryos and larvae, and detection of PmAV antiviral gene in transgenic tiger shrimp larvae were descriptively presented. The hatching rate and survival rate of tiger shrimp larvae challenged with WSSV were analyzed by variance (ANOVA) and the total weight and length of tiger shrimp in age of 1.5 months were analyzed by t-test using Statistix Version 3.0 at 5\% level. The PmAV antiviral gene expression of hepatopancreas of tiger shrimp larvae challenged by WSSV was descriptively discussed.

\section{Results}

\section{Construction of pProAV-PmAV Gene}

The pProAV-PmAV gene construct was successfully created in pBlueskript-SK vector. Cracking result showed also evidence to insertion of ProAV promoter and PmAV antiviral gene by comparing to control of blue colony bacteria (Fig. 1A). A confirmation of orientation test also showed insertion of genes in the right direction (Fig. 1B). 
Table 1: Hatching rate, DNA and cDNA detection in embryos of tiger shrimp transfected by ProAV-PmAV gene construct

\begin{tabular}{llllll}
\hline Trials & \multicolumn{3}{c}{ Hatching rate (\%) } & \multicolumn{2}{c}{ Detection*) } \\
\cline { 2 - 5 } & \multicolumn{2}{c}{ Transgenic shrimp Positive control Negative control DNA cDNA } \\
\hline 1 & $48.0 \pm 14.2^{\mathrm{a}}$ & $60.0 \pm 3.0^{\mathrm{a}}$ & $66.8 \pm 12.1^{\mathrm{a}}$ & $(+)$ & $(+)$ \\
2 & $28.1 \pm 6.4^{\mathrm{a}}$ & $26.2 \pm 6.9^{\mathrm{a}}$ & $31.2 \pm 14.4^{\mathrm{a}}$ & $(+)$ & $(+)$ \\
\hline
\end{tabular}

Notes: Numbers on the same row and followed by the same letters show no significant difference $(P>0.05)$, numbers were written in mean $\pm \mathrm{SD}, *)=$ analysis was carried out on 50 transgenic shrimp embryos (pooled sample), $(+)=$ PmAVgene was positively detected

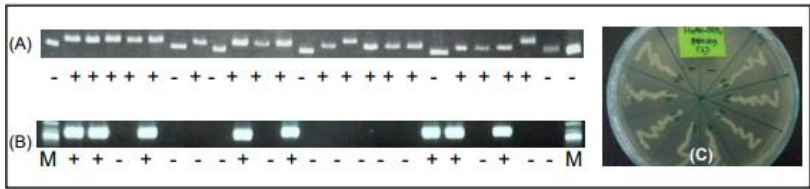

Fig. 1: Results of cracking, PCR analysis of the pProAV-PmAV gene construct, and plating of bacterial clones. $\mathbf{A}=$ cracking results of bacterial clones carrying the pProAV-PmAV gene on agarose gel where positive sign indicates clones carrying insertion gene while negative sign as clones without insertion, $\mathbf{B}=$ results of ligation orientation test in vectors where positive sign indicates a presence of band in size of approximately $1.2 \mathrm{~kb}$ indicates a correct direction while negative sign/without band indicates a wrong direction of ligation, and $\mathbf{M}$ indicates DNA marker, and $\mathbf{C}=$ plating of bacterial clones carrying the pProAV-PmAV gene construct

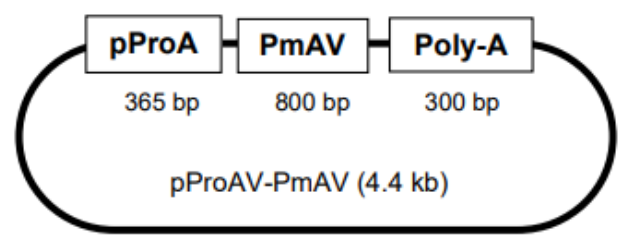

Fig. 2: Schematic structure map of pProAV-PmAV gene constructs in the pBlueskript-SK vector

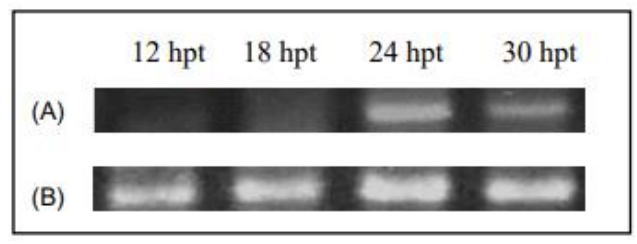

Fig. 3: Transgene expression of PmAV gene in tiger shrimp embryos and larvae. Observation of PmAV antiviral gene expression at 12, 18, 24, and 30 hours post transfection (hpt); the expression of PmAV antiviral gene (A) and shrimp $\beta$-actin gene as an internal control (B)

Positive clones carrying the ProAV-PmAV construct were then plated on the agar medium (Fig. 1C) as material to be used in further work. Fig. 1 indicated that the ProAV promoter $(365 \mathrm{bp})$ and the PmAV antiviral gene (800 bp) was successful inserted into up-stream of Poly-A the pBlueskript-SK vector. The illustration of the gene construct with the sequential component of pProAV-PmAV in vector was predicted approximately $4.4 \mathrm{~kb}$ in length. A map of the
pProAV-PmAV gene construct was presented in Fig. 2.

\section{Transfection of pProAV-PmAV construct}

The average hatching rate of tiger shrimp was no significant difference $(P>0.05)$ among treatments for both trials (Table 1). These results implied that the use of jetPEI reagent and DNA plasmid from the gene construct did not have a harmful effect on the hatchability of tiger shrimp embryos. The DNA and cDNA detection showed positively presence the exogenous antiviral genes into embryos or tiger shrimp larvae (Table 1). In the observation at $12 \mathrm{hpt}$, the expression of antiviral gene was started to weakly exhibit until $18 \mathrm{hpt}$. The expression of the antiviral gene was strongly expressed as a peaked point at $24 \mathrm{hpt}$ or one day after transfection and the expression fairly dropped at $30 \mathrm{hpt}$ (Fig. 3).

\section{Survival and overexpression of larvae}

A death of non-transgenic tiger shrimp larvae began to be significantly exhibited at $12 \mathrm{hpt}$ (day-1) after the challenge test until $72 \mathrm{hpt}$ (day-3) and after that the shrimp mortality was not significant (Fig. 4). The survival of transgenic tiger shrimp larvae was higher than that of normal shrimp larvae when challenged with WSSV, where at $120 \mathrm{hpt}$ (day-5) showed that the survival of transgenic tiger shrimp larvae (95.6\%) was significantly different $(P<0.05)$ with nontransgenic tiger shrimp larvae (positive control) (71.1\%), but not significantly different $(P>0.05)$ from nontransgenic without challenge test (negative control) (97.8\%) (Fig. 5).

After being challenged with WSSV, PmAV gene for both transgenic shrimp and non-transgenic tiger shrimp showed up-regulated response by increased induction of antiviral gene expression (Fig. 6). For transgenic tiger shrimp, PmAV antiviral gene expression began to be induced since $6 \mathrm{~h}$ after exposure and continued to increase sharply until $96 \mathrm{hpt}$ (day-4) and slightly decreased on 120 hpt (day-5) after the challenge test. While, non-transgenic tiger shrimp, even also increased induction until $24 \mathrm{hpt}$ (day1) and decreased on $48 \mathrm{hpt}$ (day-2) and then the expression showed relatively lower until the end of experiment.

\section{Growth and morphological appearance of juvenile}

Observation in the 47 days old showed that the transgenic tiger shrimp did not have morphological differences in appearance with the non-transgenic (Fig. 7). Transgenic tiger shrimp reached $0.21 \pm 0.12 \mathrm{~g}$ in body weight and $3.3 \pm 0.51$ $\mathrm{cm}$ in length, while the control shrimp (non-transgenic shrimp) had a weight of $0.30 \pm 0.16 \mathrm{~g}$ and a length of $3.5 \pm$ $0.63 \mathrm{~cm}$. Based on the t-test conducted between the two groups of shrimps showed no significant difference $(P>$ 0.05 ) both in weight and length. Furthermore, based on a long-term observation during maintenance, transgenic 


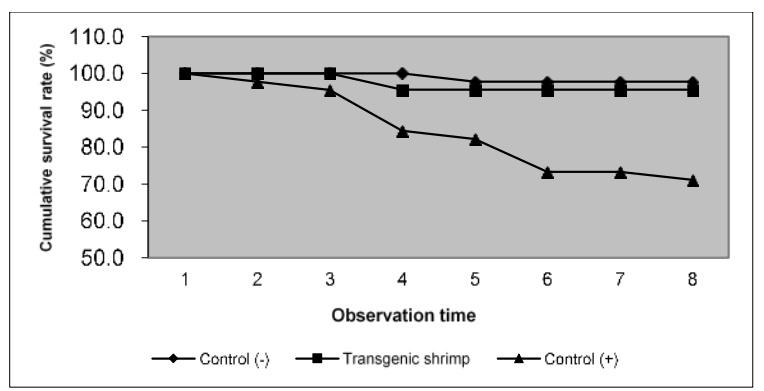

Fig. 4: Cumulative survival rate of tiger shrimp larvae challenged with WSSV. The observation time of $0 \mathrm{hpt}(1), 6 \mathrm{hpt}(2), 12 \mathrm{hpt}$ (3), $24 \mathrm{hpt}$ (4), $48 \mathrm{hpt}(5), 72 \mathrm{hpt}$ (6), $96 \mathrm{hpt}$ (7), and $120 \mathrm{hpt}$ (9) (a)

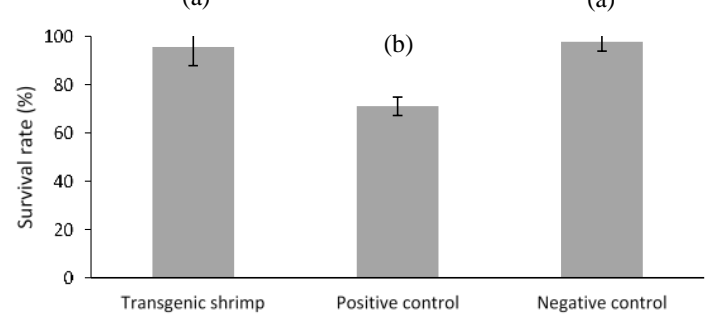

Fig. 5: Survival rate of tiger shrimp larvae at after 5 days of challenged test (Number followed by the same letter indicated no significant difference $(P>0.05)$ and bar $=$ standard deviation $)$

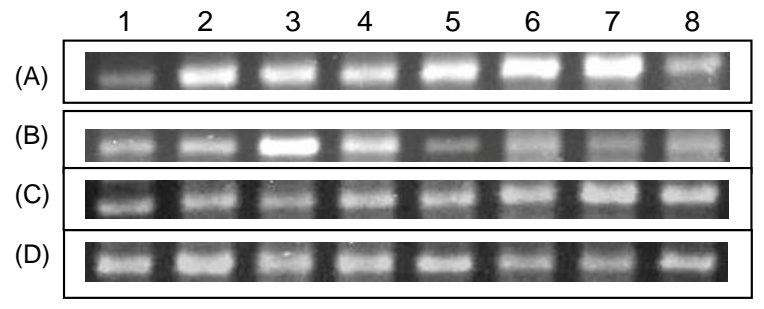

Fig. 6: PmAV antivirus gene expression in hepatopancreas of tiger shrimp challenged with WSSV. Expression in transgenic (A), nontransgenic shrimp (B), and $\beta$-actin target genes as internal controls in transgenic (C) and non-transgenic shrimp (D). Observation of PmAV gene expression at: (1) initial; (2) $6 \mathrm{hpt}$; (3) $12 \mathrm{hpt}$; (4) 24 hpt; (5) 48 hpt; (6) 72 hpt; (7) 96 hpt; and (8) $120 \mathrm{hpt}$

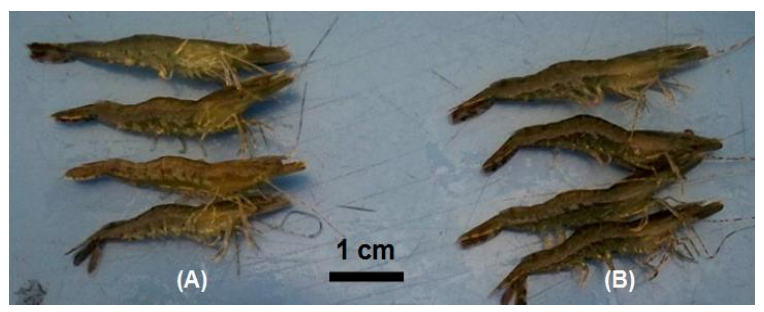

Fig. 7: Morphological appearance of transgenic (A) and nontransgenic (B) tiger shrimp juveniles at 47 days old

shrimp appeared to be relatively active, healthy with normal morphology.

\section{Discussion}

The pProAV-PmAV gene construct was successfully inserted into up-stream of Poly-A the pBlueskript-SK vector. The number of right ligation direction was relatively lower compared to the correct ligation direction in the pProAV-EGFP gene construct (86.0\%) conducted by Parenrengi et al. (2018). The low percentage of ligation in this construction was probably due to the twice gene ligation performed, firstly insertion with the ProAV promoter using the BamHI restriction site, then followed by insertion of the PmAV antiviral gene with SalI restriction site. However, the construction of ProAV-EGFP was only carried out in onestep of insertion with using the BamHI restriction site. In addition, the quality of competent bacterial cells used may differ that they influenced the success in obtaining the correct direction of ligation.

In application of jetPEI transfectian reagent to the tiger shrimp, the hatchability in this present study was relatively lower than with white shrimp L. vannamei around 50-60\% (Sun et al. 2005). This may be a different quality, species, and spawning technique of broodstock. However, the use of jePEI and gene construct plasmid did not have a negative effect to the hatching rate of tiger prawn larvae. The previous studies also reported that the tranfection of gene construct plasmid did not show a harmful impact to the embryos (Sheela et al. 1998; Yasawa et al. 2005) Although a transfection method in L. vannamei showed a better technique compared to electroporation and microinjection, in terms of egg hatchability produced (Sun et al. 2005), the microinjection in medaka fish Oryzias latipes offered a fairly high hatching rate of $70 \%$ (Winkler et al. 1991), in catfish Clarias spp. reaching 55.0-93.3\% (Ath-Thar 2007), and in sea bream Pagrus major around 53-63\% (Kato et al. 2007).

Antiviral gene expression in tiger shrimp embryos/larvae (Fig. 3) showed a closely similarity pattern with expression of EGFP gene in tiger shrimp embryo/larvae (Parenrengi et al. 2018). This indicated that the expression of transgene began to decrease after the eggs hatched into naupli. Based on several studies, foreign gene expression generally started after the mid-blastula phase and its level increased during embryogenesis stage, and then decreased after hatching (Alimuddin 2003).

The present study exhibited the expression on the larvae of transgenic tiger shrimp. Increasement of transient expression occurred during the process of extrachromosomal replication of foreign DNA, and subsequently the level of expression decreased due to degradation of exchromosomal foreign DNA. Transient expression of the hrGFP gene which was controlled by the $\beta$-actin promoter of medaka fish in catfish Clarias spp. was started to exhibit, even still very weak, at $4 \mathrm{~h}$ after microinjection, and then the expression increased at $8^{\text {th }}$ and $12^{\text {th }} \mathrm{h}$ and thereafter until $24^{\text {th }} \mathrm{h}$, a sign of decreased expression occurred and finally undetected (Aththar 2007). By using the same promoter, GFP expression in carp Cyprinus carpio showed a similar pattern to catfish, 
where the highest expression level was obtained at 12 to $18 \mathrm{~h}$ after microinjection and then after hatching the expression begun to decline until it was not visible in 1-day old larvae (Purwanti 2007).

The insertion of the PmAV antiviral gene into tiger shrimp embryos or larvae was a major indicator of the success of gene transfer. Genomic DNA analysis in the present study showed that the percentage of tiger shrimp carrying the exogenous PmAV gene was 37.5-75.0\%. The efficiency of transfer of foreign genes to embryos is influenced by the different transfer method and species. Some researchers reported their success in introducing foreign genes into crustacean embryos. The rate of gene introduction in shrimp Marsupenaeus japonicus was relatively low at $1 \%$ only for the microinjection and $0.42 \%$ for the particle-bombardment method. Use of electroporation technique, Arenal et al. (2008) reported that the transfection efficiency to the white shrimp L. schmitti embryo was up to $36 \%$. The high efficiency (72\%) of TSVCP gene introduction has been reported by Sun et al. (2005) in shrimp L. vannamei using the transfection method. Furthermore, by electroporation method, Tseng et al. (2000) have proven that bacterial alkaline phosphatase (BAP) gene transfer was integrated in the tiger shrimp genome, in rate of $31 \%$. The integration of introduced gene into Indian carp Labeo rohita has been reported by Rajesh and Majumdar (2005) using the southern hybridization method. These several successes showed that the transfer of foreign genes to shrimp embryos is no longer a main obstacle in the development of transgenic shrimp production.

The result of WSSV challenge test on tiger shrimp larvae was obviously revealed that the immune response, in term of survival rate, of transgenic shrimp was higher than that of non-transgenic shrimp larvae. Shrimp mortality was indicated by change in feed response decrease, unstable swimming activity, always at the bottom and the appearance of reddish body colour, as well as white spots on the carapace. A similar symptom of pathological changes was also reported by Alifuddin et al. (2003) in the study of WSSV transmission in tiger shrimp larvae. Furthermore, it was noted that the characteristic of cellular changes by WSSV virus infection in tiger shrimp was the inflammation of the cell nucleus (hypertrophy) due to the development and accumulation of virions by developing in the cell nucleus, moving sideways, then karyolitic occurs to eventually lysis cells. The damage cell contributes to the cause of the death of tiger shrimp.

Alifuddin et al. (2003) reported that an average survival rate by exposure with WSSV in tiger shrimp larvae was 73.3-91.7\%, compared to all survive of larvae without challenged test. The present study indicated survival rate enhancement by $24.5 \%$ higher than non-transgenic shrimp. This implied that overexpression of the PmAV antiviral gene played an important factor to increase tiger shrimp resistance to WSSV. Increased resistance of shrimp $L$. vannamei through TSV-CP gene transfer has been reported by Lu and Sun (2005), where transgenic shrimp larvae had a higher resistance with $83 \%$ survival compared to control shrimp of only $44 \%$ when challenged with TSV.

Comparing with the conventional fish immunization, some advantages have been claimed for immunity enhancement using transgene technology. Fish can be protected from the larval development, before the immune system started to mature immunity (Dunham 2009). Gene encoding antimicrobial peptides such as cecropin regulated by CMV promoter increased the resistance to bacterial disease in channel fish Ictalurus punctatus up to 2-4 times (Dunham et al. 2002). Transgenic catfish that carry preprocecropin gene construct showed very high survival $(100 \%)$ when exposed to bacterium Plavobacterium columnare compared to control fish which was only $27.3 \%$. Meanwhile, when challenged with bacterium Edwardsiella ictaluri, transgenic catfish also showed high survival (40.7\%) compared to non-transgenic fish (14.8\%). Sarmasik et al. (2002) reported that the second generation of transgenic medaka fish showed high resistance to Pseudomonas fluorescens with a mortality rate of $0-10 \%$ compared to control 40\%, and when challenged with Vibrio anguillarum, transgenic medaka fish were still able to survive $70-90 \%$ while the control was only around $60 \%$.

The highest increased expression on day-4 of this present study was agreed with previous research on the Ctype lectin gene on white shrimp L. vannamei (Luo et al. 2007). Luo et al. (2007) also reported the naturally occurring expression of the PmAV antiviral gene in nontransgenic shrimps when challenged with WSSV, where hepatopancreas had the greatest antiviral gene expression, 700 times higher than in the muscle. Furthermore, the expression pattern of the PmAV antiviral gene was equivalent to the WSSV virus load in the body of tiger shrimp. When white shrimp L. vannamei challenged with WSSV, the C-type lectin gene expression initially decreased on day 2 , but thereafter increased sharply until it peaked on day-4 (Ma et al. 2007). Somboonwiwat et al. (2006) reported an increasement of gene expression level of interferon-related developmental regulator-1, glucose transporter-1, lysozyme, profiline, and serpine -B3 in $P$. monodon haemocyte after exposed to pathogens, and that these genes had as up-regulated gene expression. When challenged with pathogens, the penaeidin antibacterial gene showed a strong expression in shrimp L. vannamei (Destoumieux et al. 2000) and Fenneropenaues chinensis (Kang et al. 2007). The expression of the Rab GTPase gene in shrimp $P$. japonicus was induced when challenged with the WSSV (Wu and Zhang 2007), and lysozyme genes in $L$. vannamei when injected with Vibrio campellii (Burge et al. 2007).

Related to this finding of tiger shrimp juvenile observation, Lu and Sun (2005) reported on 236 days old of transgenic white shrimp did not show morphological differences with non-transgenic white shrimp, in term of weight $7.67 \mathrm{~g}$ and $9.17 \mathrm{~g}$, respectively. Indeed, Lu and Sun 
(2005) stated that the decrease in weight gain was probably caused by the integration of target genes introduced into specific areas of the genome, which slightly influenced on the initial growth of white shrimp larvae.

This present study implied that the results of PmAV antiviral gene expression analysis in embryos and larvae showed strong evidence to the success in transferring the pProAV-PmAV gene construct into the tiger shrimp. Meanwhile, observing the survival rate and antiviral genes expression of tiger shrimp when challenged with WSSV provided a general description of the involvement of the PmAV antiviral gene in enhancing the immune system of tiger shrimp.

\section{Conclusion}

The pProAV-PmAV gene has been successfully constructed and introduced to the tiger shrimp embryo through a transfection method. The overexpression of PmAV antiviral gene could enhance the resistance to WSSV infection and did not have a negative affect to the growth and morphological appearance of tiger shrimp. This work may demonstrate an important implication for commercial tiger shrimp aquaculture.

\section{Acknowledgements}

We are grateful to the Ministry of Marine Affairs and Fisheries, Republic of Indonesia for funding this study through the DIPA of Research Institute for Brackishwater Aquaculture and Fisheries Extension (RIBAFE). We also thank to researchers and technicians at Biotechnology Laboratory of Research Institute for RIBAFE, technicians of Animal Aquatic Laboratory of IPB University and to all those who gave assistance to support this present study.

\section{Author Contributions}

AP and AT planned the research, performed the experiment/data analysis, drafted the manuscript and made illustrations; AA and SS supervised the work, aided in interpreting the results and revised manuscript; All authors provided critical feedback and helped shape the research.

\section{References}

Alifuddin M, D Dana, M Eidman, MB Malole, FH Pasaribu (2003). White spot disease in black tiger shrimp (Penaeus monodon Fab.): transmission through immersion with white spot viruses 20,100, and $200 \mu \mathrm{g} / \mathrm{mL}$ with an exposure time of $120 \mathrm{~min}$. J Akuakult Indones $2: 31-35$

Alimuddin (2003). Introduction and expression of foreign $\Delta 6$-desaturaselike gene in a teleostean fish. Thesis. Tokyo University of Fisheries, Japan

Alzaid A, JH Kim, RH Devlin, SAM Martin, DJ Macqueen (2018). Growth hormone transgenesis in coho salmon disrupts muscle immune function impacting cross-talk with growth systems. J Exp Biol 221:1-10
Anderson ED, DV Mourich, SC Fahrenkrug, S LaPatra, J Shepherd, JA Leong (1996). Genetic immunization of rainbout trout (Oncorhynchus mykiss) against infectious hematopoietic necrosis virus. Mol Mar Biol Biotechnol 5:114-122

Arenal A, R Pimentel, E Pimentel, L Martin, D Santiesteban, R Franco, P Alestro (2008). Growth enhancement of shrimp (Litopenaeus schmitti) after transfer of tilapia growth hormone gene. Biotechnol Lett 30:845-851

Ath-Thar MHF (2007). Effectiveness of $\beta$-actin promoter of medaka fish Oryzias latipes with a marker of the hrGFP (humanized Renilla reniformis green fluorescent protein) gene in catfish Clarias spp. Descendants of F0. Thesis. Ministry of Aquaculture, Faculty of Fisheries and Marine Sciences, Bogor Agricultural University

Austin B, D Allen-Austin (1985). A review: bacterial pathogens of fish. $J$ Appl Microbiol 58:483-506

Bevins CL, M Zasloff (1990). Peptides from frog skin. Annu Rev Biochem 59:395-414

Burge EJ, DJ Madigan, LE Burnett, KG Burnett (2007). Lysozyme gene expression byhemocytes of Pacific white shrimp Litopenaeus vannamei, after injection with Vibrio. Fish Shellf Immunol 22:327-339

Chiou PP, MJ Chen, CM Lin, J Khoo, J Larson, R Holt, JA Leong, G Thorgarrd, TT Chen (2014). Production of homozygous transgenic rainbow trout with enhanced disease resistance. Mar Biotechnol 16:299-308

Destoumieux D, M Munoz, C Cosseau, Rodriguez, P Bulet, M Comps, E Bachere (2000). Penaeidins, antimicrobial peptide with chitinbinding activity, are produced and stored in shrimp granulocyte and released after microbial challenge. J Cell Sci 113:461-469

Destoumieux D, P Bulet, D Loew, AV Dorsselaer, J Rodriguez, E Bachere (1997). Penaeidins, a new family of antimicrobial peptide isolated from the shrimp Penaeus vannmaei (Decapoda). J Biol Chem 272:28398-28496

Dunham RA (2009). Transgenic fish resistant to infectious diseases, their risk and prevention of escape into the environment and future candidate genes for diseases transgene manipulation. Compar Immunol Microbiol Infect Dis 32:139-161

Dunham RA, G Warr, A Nichols, PL Duncan, B Argue, D Middleton, Z Liu (2002). Enhanced bacterial diseases resistance of transgenic channel catfish Ictalurus punctatus possessing cecropin genes. Mar Biotechnol 4:338-344

Escobedo-Bonilla CM (2011). Application of RNA interference (RNAi) against viral infections in shrimp: a review. J Antivir Antiretrovir 2011; Article S9

Hoffmann JA, JM Reichhart, C Hetru (1996). Innate immunity in higher insects. Curr Opin Immunol 8:8-13

Kang CJ, JF Xue, N Liu, XF Xhao, JX Wang (2007). Characterization and expression of a new subfamily member of penaeidin anti-microbial peptides (penaeidin 5) from Fenneropenaeus chinensis. Mol Immunol 44:1535-1543

Kato K, M Takagi, Y Tamaru, SI Akiyama, T Konishi, O Murata, H Kumai (2007). Construction of an expression vector containing a $\beta$-actin promoter region for gene transfer by microinjection in red sea bream Pagrus major. Fish Sci 73:440-445

Lehrer RI, AK Lichtenstein, T Ganz (1993). Defensins: Antimicrobial and cytotoxic peptides of mammaliancells. Annu Rev Immunol 11:105-128

Linacero RJ, Rueda, AM Vazquez (1998). Quantification of DNA. In: Molecular Tools for Screening Biodiversity: Plants and Animals, pp:1-21. Karp AP, G Isaac, DS Ingram (Eds.). Chapman and Hall. London, Weinheim, New York, Tokyo, Melbourne, Madras

Lu Y, PS Sun (2005). Viral resistant in shrimp that express an antisense Taura syndrome virus coat protein gene. Antivir Res 67:141-146

Luo T, L Fang, L Kaiyu, X Xu (2007). Genomic organization, promoter characterization, and expression profiles of an antiviral gene PmAV from the shrimp Penaeus monodon. Mol Immunol 44:1516-1523

Ma TH, SHK Tiu, JG He, SM Chan (2007). Molecular cloning of a C-type lectin (LvLT) from the shrimp Litopenaeus vannamei; Early gene down-regulation after WSSV infection. Fish Shellf Immunol 23:430-437 
McClelland EK, MTT Chan, X Lin, Sakhrani, FD Vincelli, JH Kim, DD Heath, RH Devlin (2020). Loci associated with variation in gene expression and growth injuvenile salmon are influenced by the presence of a growth hormone transgene. BMC Genomics 21; Article 185

Parenrengi A, R Syah, A Tenriulo (2018). Analysis of promoter activity on tiger shrimp Penaeus monodon using EGFP (enhanced green fluorescent protein) as a marker gene. Aquacult Aquar Conserv Legislat 11:1937-1946

Parenrengi A, A Alimuddin, S Sukenda, K Sumantadinata, M Yamin, A Tenriulo (2009a). Cloning of ProAV promoter isolated from tiger prawn Penaeus monodon. Indones Aquacult J 4:1-7

Parenrengi A, S Alimuddin, K Sumantadinata, A Tenriulo (2009b). Characteristic of cDNA sequence encoding antivirus gene from tiger shrimp, Penaeus monodon. J Riset Akuakult 4:1-13

Purwanti LI (2007). Test of $\beta$-actin promoter activity of medaka fish (Oryzias latipes) in carp (Cyprinus carpio). Thesis. Faculty of Fisheries and Marine Sciences, Bogor Agricultural University, Java, Indonesia

Rajesh R, KC Majumdar (2005). Transgene integration - an analysis in autotrangenic Labeo rohita Hamilto (Pisces: Cyprinidae). Fish Physiol Biochem 31:281-287

Sarmasik A, G Warr, TT Chen (2002). Production of transgenic medaka with increased resistance to bacterial pathogen. Mar Biotechnol 4:310-322

Sheela SG, JD Chen, S Mathavan, TJ Pandian (1998). Construction, electroporatic transfer and expression of ZpßypGH and $\mathrm{ZpßrtGH}$ in zebrafish. J Biosci 23:565-576

Somboonwiwat K, P Supungul, V Rimphanitchayakit, T Aoki, I Hirono, A Tassanakajon (2006). Differentially expressed genes in hemocytes of Vibrio harveyi-challenged shrimp Penaeus monodon. J Biochem Mol Biol 39:26-36
Sriphaijit T, S Senapin (2007). High expression of a novel leucine-rich repeat protein in hemocyte and lymphoid organ of the black tiger shrimp Penaeus monodon. Fish Shellf Immunol 22:264-271

Steiner H, D Hultmark, A Engstrom, H Bennich, HG Boman (1981). Sequence and specificity of two antibacterial proteins involved in insect immunity. Nature 292:246-258

Sun PS, NC Venzon, FRO Calderon, DM Esaki (2005). Evaluation of methods for DNA delivery into shrimp zygotes of Penaeus (Litopenaeus) vannamei. Aquaculture 243:19-26

Traxler GS, E Anderson, SE LaPatra, J Richard, B Shewmaker, G Kurath (1999). Naked DNA vaccination of Atlantic salmon Salmo salar against IHNV. Dis Aquat Organ 38:183-190

Tseng FS, HJ Tsai, IC Liao, YL Song (2000). Introducing foreign DNA into tiger shrimp (Penaeus monodon) by electroporation [abstract]. Theriogenology 54:1421-1432

Wakchaure R, S Ganguly, K Qadri, PK Praveen, T Mahajan (2015). Importance of transgenic fish to global aquaculture: A review. Fish Aquacult $J$ 6:1-3

Winkler C, JR Vielkind, M Schartl (1991). Transient expression of foreign DNA during embryonic and larval development of the medaka fish (Oryzias latipes). Mol Gen Genet 226:129-140

Wu W, X Zhang (2007). Characterization of a RAB GTPase up regulated in the shrimp, Penaeus monodon by virus infection. Fish Shellf Immunol 23:438-445

Yasawa R, K Watanabe, T Koyama, L Ruangapan, A Tassanakajon, I Hirono, T Aoki (2005). Development of gene transfer technology for black tiger shrimp, Penaeus monodon. J Exp Zool 303:1104-1109 